\title{
An evaluation of small businesses in Iran
}

\author{
Ahmad Jafari Samimi ${ }^{a}$, Mahmood Yahyazadefar ${ }^{b}$, Hasanali Aghajani ${ }^{b}$ and Seyed Mohammad karimi ${ }^{{ }^{*}}$
}

${ }^{a}$ Professor of Economics, University of Mazandaran, Babolsar, Iran

${ }^{b}$ Associate Professor of Management, University of Mazandaran, Babolsar, Iran

${ }^{c}$ Department of Management, Economics University of Mazandaran, Babolsar, Iran

\section{H R O N I C L E}

Article history:

Received January 15, 2013

Received in revised format

9 April 2013

Accepted 10 April 2013

Available online

April 112013

Keywords:

Small businesses

Self-employment

Entrepreneurship

\section{A B S T R A C T}

As one of the most important and fundamental issues, employment is an indicator of development and welfare in any country. Due to the rapid growth of population over the past decades in Iran, investigating unemployment and the obstacles hindering employment is of paramount importance. In this study, a questionnaire was used and a group of experts were interviewed in order to identify four groups of legal, economic, social as well as individual factors, which could improve or hinder the growth of small businesses and self-employment. In this paper, having determined the factors influencing the expansion or downsizing the small businesses, the entrepreneurs, agents supporting small businesses, and the members of employment groups in Mazandaran Province, Iran rated the four categories. Finally, the most important growth factors or challenges faced by small businesses from the three aforementioned perspectives were compared.

\section{Introduction}

Unemployment is one of the most important issues in today's economy and the negative consequences of unemployment, particularly among young people may create various social issues in any developing countries including Iran. According to "Iranian Consensus Center" statistics, Iran with a population of over 75 million had an unemployment rate of $14 \%$. Hence, it is imperative to determine the major causes of unemployment and to remove the obstacles of self-employment in order to reduce unemployment rates. Economic theories that are used for analyzing self-employment are very close to the concepts of entrepreneurship (Balkin, 1989). According to the definitions of the Iranian Consensus Center, any workshops with up to 10 workers are categorized as small-scale industries. Additionally, the Iranian Ministry of Industry has classified workshops with fewer than 4 workers as "very small units", those with 5-9 workers as "small units", 10-49 workers as "medium units" and any firm with more than 50 workers is considered as "large units".

*Corresponding author.

E-mail addresses: smkarimi313@yahoo.com (S. M. Karimi) 
Small businesses have different advantages; it can decrease the rate of poverty and increase in the relative welfare level of a country and many people have managed to win Nobel prize for contributing to small businesses. One of the ways to support small businesses is to create job opportunities and a stable income for households. Small scale loans granted in Iran, for instance, by organizations like the Mehr-e-Emam Reza institute, Imdad Committee etc. can be categorized under these loans.

During the past two decades, several organizations have been established in Iran to enhance employment. For instance, in 1994, the “Qarz-ol Hasaneh" institute of job opportunities was established to support the existing jobs and to create new job opportunities. In addition, in 2000, "Qarz-ol Hasaneh" institute of rural job development was established to provide loans with no interest rate for people in underdeveloped rural areas. Furthermore, to encourage people to invest more on the agricultural industry, the core specialized organization of support and expansion of agriculture in 2003 was established to create job opportunities in the aforementioned areas (Research and Development Center of Majlis of Iranian Parliament, 2010).

According to Banerjee and Newman (1990), the affluent can obtain credit easily and create jobs; however, they often tend to own their own businesses. One of the effective measures taken in Iran in order to develop and support small businesses of low income individuals was the establishment of "Mehr-e-Reza" institute in 2005. In order to actualize the objective of employment, this organization grants employment loans with zero-interest rates. Its facilities cover unemployed individuals who are skilled in the areas of public service, industry, agriculture and business.

This research investigates the influential factors in developing small businesses. The methods of data collection involve interviews with the senior directors of "Mehr-e-Reza" institute , a survey of the entrepreneurs' views in the Province of Mazandaran as well as individuals' feedbacks who are active supporters of small scale businesses.

\section{Background and theoretical framework}

Iran is a country where the family plays essential role in social and ideological systems. The considerably increasing number of university students and high interest levels among females in social activities accentuates the need for small scale home businesses. One of the theories, often discussed in this area, is the theory of occupational choice. This theory was initially based on the neoclassic theory of human investment that regards every individual as interested in choosing a profession that leads him/her to the highest possible income (Becker, 1964). As Parker (2004) states, the occupational choice is regarded as an internal economic theory. Lucas (1978) developed a model, according to which a person can opt for either paid employment or entrepreneurship, depending on his/her leadership skills. Less talented entrepreneurs usually follow businesses that have already been tried whereas talented entrepreneurs create new businesses. Medium level entrepreneurs are also able to run their own innovative businesses or buy them from talented entrepreneurs (Holmes \& Schmitz, 1990). Fetzer (1998) stated that previous job experience and training as the most important reasons for self-employment. According to Lazear (2002), a self-employed person, who does not have access to the appropriate workforce, requires less skill in comparison to more prominent businessmen.

Cagetti and Nardi (2006) proposed their model based on individuals' ability to launch a business with a focus on income under a high financial pressure. Jacobs (2007), in their examination of the occupational choice theory, highlighted the importance of training. Jacobs's occupational choice theory indicated that self-employed individuals could earn less than regular wage earners. Antunes and Cavalcanti (2002) developed the model of general equilibrium, which contains an integration of credits. The model proposed three alternatives and an increase in unemployment represented a decrease on employment opportunities as well as one's expected income, which in turn promotes self- 
employment. Verheul et al. (2006) stated that a decrease in unemployment rates could motivate selfemployment. The choice of one's occupation is evaluated by the level of one's talent, which is performed through training. Individuals who have completed advanced training courses can employ people (Poschke, 2009). Self-employment depends on the business cycle; that is to say, during unemployment self-employment remains the only alternative in the job market, and vice versa during an economic boom fewer people try self-employment (Verheul et al., 2006). Berger and Black (2011) investigated the effect of granting loans on small-scale businesses and pointed out the advantages of loans granted by small banks to small businesses. Kaiser and Moller (2011) tried to find out whether self-employment was an unpleasant and unsuccessful experience, investigated the effects of selfemployment and working for wages on employment. In a study in Spain, 700 small business owners were surveyed on self-employment and innovation and different factors influencing innovation in small business were determined (Romero \& Martínez-Román, 2012). Romero and Roman (2012) reported training as the most influential factor.

The present study seeks to determine the factors influencing the growth of small businesses and the obstacles hindering their development from the viewpoint of agents supporting small businesses, entrepreneurs, and the members of employment groups.

\section{Method}

This study conducted in Mazandaran Province of Iran, aims at identifying the best way to support small businesses and it comprises two phases. The first phase involves determining the factors influencing the small businesses and the second one focuses on ranking these factors from the viewpoint of agents supporting small businesses, entrepreneurs, and the members of employment groups. Both descriptive and inferential statistics have been used to analyze the data.

\subsection{Population and Sample}

The sample size of the present study was 152 including the agents supporting small businesses and the members of employment groups in Mazandaran Province and 30 successful entrepreneurs in the province who had used the facilities of Mehr-e-Emam Reza institute in order to establish or expand small businesses. The sample also comprised the senior directors of Mehr-e-Emam Reza institute, who shared their knowledge and expertise with the researchers.

\subsection{Research Procedure}

In this study, in order to find out the factors influencing the small businesses the following procedures were followed and were presented in Fig. 1.

- Determining the factors that influence the growth of the small businesses by interviewing the experts in Mehr-e-Emam Reza institute: The factors and challenges influencing the growth of the small businesses were identified through interviews and focus group meetings with the experts of the organization.

- Classifying the factors in four categories of economic, legal, social and individual factors with the help of the experts and based on the literature related to employment in different organizations in Iran and the world. Interviews and focus group meetings were conducted to refine this classification.

- Using statistical methods to rate the influencing factors on the small businesses based on the viewpoints of three different groups including the agents supporting small businesses, entrepreneurs, and the members of employment groups 
- Cross-checking the results achieved from the viewpoints of the three aforementioned groups and analyzing the results

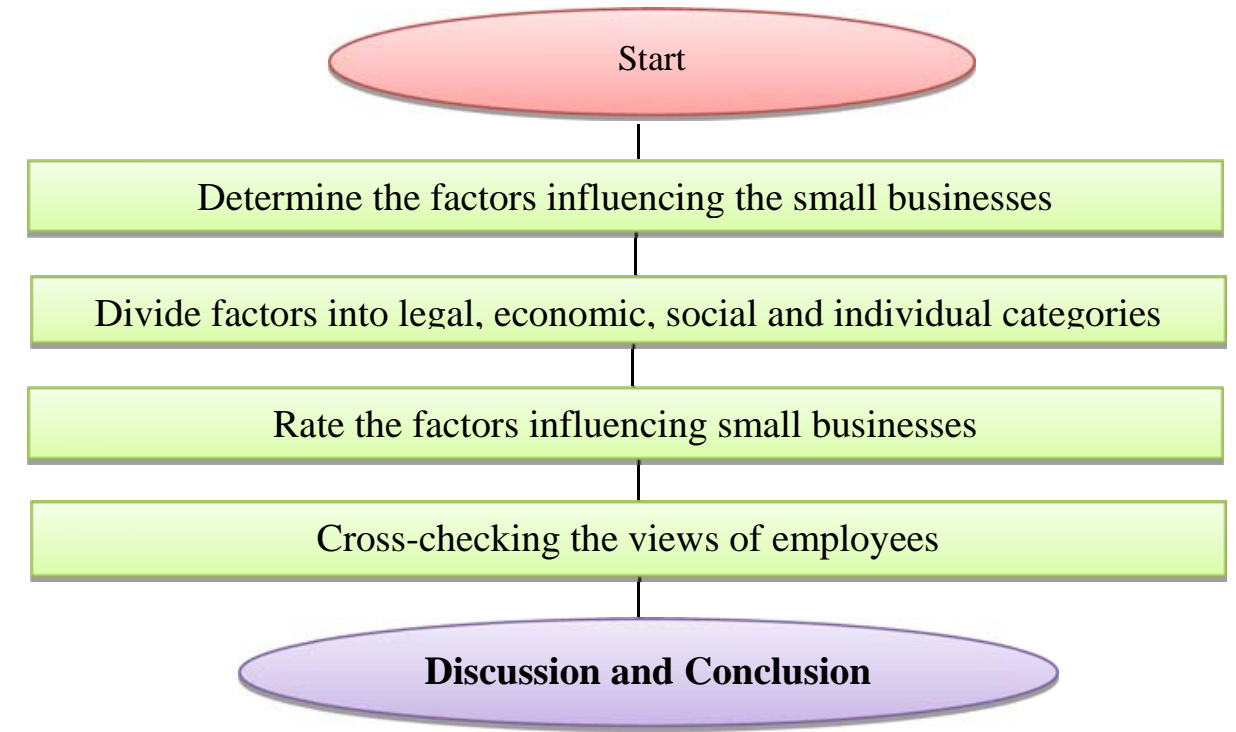

\section{Data analysis}

Fig. 1. Research procedure

Phase 1: In this phase, we determine the factors influencing the small businesses through interviews with the experts in Mehr-e-Emam Reza institute. This phase involved interviewing 11 senior directors of Mehr-e-Emam Reza institute on the factors that positively or negatively influence the small businesses. After collecting the data, the researchers examined the responses in order to categorize the factors (Table 1).

Phase 2: In this phase, we classify the factors into legal, economic, social and individual categories The experts in the area of employment were interviewed and the related literature on the viewpoints of Iranian scholars as well as researchers from other parts of the world were reviewed in order to categorize the identified factors in Phase 1 under four categories of legal, economic, social and individual factors (Table 1):

Table 1

Factors influencing small businesses

\begin{tabular}{|c|c|c|c|c|}
\hline \multirow{2}{*}{ Effect } & \multicolumn{4}{|c|}{ Factors } \\
\hline & Economic & Legal & Social & Individual \\
\hline Positive & $\begin{array}{l}\text { - Tax reduction/ } \\
\text { exemption } \\
\text { - Increased export } \\
\text { - Financial aids with } \\
\text { low interest rates } \\
\text { and costs }\end{array}$ & $\begin{array}{l}\text { - } \text { Increasing wages } \\
\text { - } \text { Limited } \\
\text { employment in } \\
\text { governmental } \\
\text { sections } \\
\text { - } \text { Restrictions in } \\
\text { employing } \\
\text { foreigners }\end{array}$ & $\begin{array}{ll}\text { - } & \text { Increased } \\
\text { investment in } \\
\text { vocational training } \\
\text { - } \quad \text { Training during } \\
\text { military service } \\
\text { - Supporting home } \\
\text { businesses } \\
\text { - Encouraging team } \\
\text { work and } \\
\text { collaboration }\end{array}$ & $\begin{array}{ll}\text { - } & \text { Increasing } \\
\text { individuals' risk- } \\
\text { taking attitudes } \\
\text { - } & \text { Independence } \\
\text { - } & \text { Self-confidence } \\
\text { - } & \text { Creativity }\end{array}$ \\
\hline Negative & 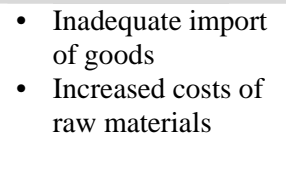 & $\begin{array}{l}\text { - Inadequate financial } \\
\text { and monetary } \\
\text { policies } \\
\text { - Restrictions in } \\
\text { obtaining permits }\end{array}$ & & $\begin{array}{l}\text { - A tendency to do } \\
\text { routine and } \\
\text { monotonous work }\end{array}$ \\
\hline
\end{tabular}

Phase 3: In this phase, we rate the factors influencing small businesses through statistical analysis of the data. A questionnaire was developed and tested for its reliability by administrating it to 20 
randomly selected target respondents. The obtained Cronbach's alpha coefficient was .816 that was more than .70 that would indicate a high level of reliability. The data were tested for their normality before deciding on the most appropriate statistical method to test the research hypotheses. KS test was used to test the normality of distribution of the data. Since the significant value exceeded alpha at .05 ( $p>.05$ ), it was concluded that the data were normally distributed. In order to rate the four factors Freedman's test was used. Based on the results of this test, since the significant value was smaller than alpha $(p<.05)$, it was concluded that the four factors had different degrees of effects on small businesses. The rank of each factor was determined based on the calculated means:

\section{Table 2}

Ranking the factors influencing small businesses

\begin{tabular}{lc}
\hline Factors with descending level of importance & Means \\
\hline Economic factors & 3.27 \\
Social factors & 2.84 \\
Individual factors & 2.10 \\
Legal factors & 1.80 \\
\hline
\end{tabular}

Phase 4: In this phase we perform cross-checking the views of employees in the agents supporting small businesses, entrepreneurs, and the members of employment groups through statistic tests. In this phase, ANOVA was used to compare the means of the four factors achieved from the three different sources of data. As the results of the test indicated, the significant value was larger than alpha ( $p>.05)$. It was, therefore, concluded that there was no significant difference between the effects of the four factors on small businesses.

Table 3

Ranking the factors influencing small businesses from various viewpoints

\begin{tabular}{|c|c|c|c|}
\hline Sample & Factor & Mean & The most important factor \\
\hline \multirow[t]{4}{*}{ Entrepreneurs } & Economic & 3.00 & \multirow[t]{4}{*}{ Increased export } \\
\hline & Legal & 1.67 & \\
\hline & Social & 2.83 & \\
\hline & Individual & 2.50 & \\
\hline \multirow{4}{*}{$\begin{array}{l}\text { Agents supporting small } \\
\text { businesses }\end{array}$} & Economic & 3.29 & \multirow{4}{*}{$\begin{array}{l}\text { Financial aids with low } \\
\text { interest rates and costs }\end{array}$} \\
\hline & Legal & 1.80 & \\
\hline & Social & 2.84 & \\
\hline & Individual & 2.08 & \\
\hline \multirow{4}{*}{$\begin{array}{l}\text { Members of employment } \\
\text { group }\end{array}$} & Economic & 3.05 & \multirow[t]{4}{*}{ Inadequate import of goods } \\
\hline & Legal & 1.77 & \\
\hline & Social & 2.97 & \\
\hline & Individual & 2.22 & \\
\hline
\end{tabular}

In order to determine how each of the three sources of data rated the influential factors, Freedman test was used. As the results showed, the significant value was smaller than alpha $(p<.05)$. It was, therefore, concluded that the effect of each of the four factors was significantly different based on the viewpoints of the three sources. Then, the most influential factors were determined in reference to the viewpoints of the three sources of data. Table 3 summarizes the findings on the most influential factors based on the means of the rankings.

\section{Discussion and Conclusion}

Based on the findings we understand that the factors influencing the growth of the small businesses in Mazanadaran Province of Iran include economic, social, legal and individual factors, in reference to their degree of importance. The main factors influencing the small businesses were rated similarly by the three different sources (entrepreneurs, agents supporting small businesses, and members of employment groups). The four factors included the economic, social, legal and individual factors in 
reference to their level of importance. In our survey, economic factors are the most important factors for the growth of the small businesses in Iran, followed by the social factors.

Based on the feedback received from the entrepreneurs and self-employed individuals in small businesses, among the 20 factors, the most influential factors that can improve small businesses include (a) increasing export, (b) supporting small and home businesses run by women who are financially in charge of their households and providing their means of sustenance, and (c) financial support of the small business owners by providing them low interest financial support and low cost facilities in the order of their importance.

According to the employment group members in Mazandaran Province, an inadequate rise in import of goods is the most remarkable obstacle in the way of the growth of small businesses. Meanwhile, an increase in export besides the individual's self-confidence and perseverance can positively affect the growth and development of self-employment and small businesses. Individuals who work in agencies supporting small businesses, like Mehr-e-Emam Reza institute, believe that the government's financial support of the small business owners and their access to low interest financial resources as well as low cost facilities are the most important factors that support the growth of small businesses, followed by avoiding inadequate increase of import of goods as well as an increase in exports.

\section{References}

Antunes, A. R., \& Cavalcanti, T. V. (2002). Entrepreneurship and Informal Markets.

Balkin, S. (1989). Self-employment for low-income people. One Madison Avenue, NY: Praeger Publishers.

Banerjee, A. V., \& Newman, A. F. ( 1990). Occupational Choice and the Process of Development. Discussion Papers 911, 1-25.

Becker, G. S. (1964). Human Capital: A Theoretical and Empirical Analysis, with Special Reference to Education, by Gary S. Becker.

Berger, A. N., \& Black, L. K. (2011). Bank size, lending technologies, and small business finance. Journal of Banking \&amp; Finance, 35(3), 724-735.

Cagetti, M., \& De Nardi, M. (2006). Entrepreneurship, frictions, and wealth. Journal of Political Economy, 114(5), 835-870.

Fetzer, J. (1998). Who is Likely to Become Self Employed in Vietnam?

Holmes, T. J., \& Schmitz, J. A., Jr. (1990). A Theory of Entrepreneurship and Its Application to the Study of Business Transfers. Journal of Political Economy, 98(2), 265-294.

Iranian Consensus Center from http://amar.sci.org.ir

Jacobs, G. (2007). An Occupational Choice Model for Developing Countries.

Kaiser, U., \& Malchow-Møller, N. (2011). Is self-employment really a bad experience?: The effects of previous self-employment on subsequent wage-employment wages. Journal of Business Venturing, 26(5), 572-588.

Lazear, E. P. (2002). Entrepreneurship. National Bureau of Economic Research Working Paper Series, No. 9109.

Lucas, R. E., Jr. (1978). On the Size Distribution of Business Firms. The Bell Journal of Economics, 9(2), 508-523.

Mehr-e-Emam Reza institute from www.mehrereza.ir

Parker, S. C. (2004). The economics of self-employment and entrepreneurship: Cambridge University Press.

Poschke, M. (2009). Who Becomes an Entrepreneur? Labor Market Prospects and Occupational Choice.

Research and Development Center of Majlis (Iranian Parliament). from http://rc.majlis.ir/fa/law

Romero, I., \& Martínez-Román, J. A. (2012). Self-employment and innovation. Exploring the determinants of innovative behavior in small businesses. Research Policy, 41(1), 178-189.

Verheul, I., Stel, A. V., \& Thurik, R. (2006). Explaining female and male entrepreneurship at the country level. Entrepreneurship \& Regional Development, 18(2), 151-183. 